\title{
WestVirginiaUniversity
}

THE RESEARCH REPOSITORY @ WVU

Volume 28 | Issue 1

Article 22

November 1921

\section{Virginia Colonial Decisions}

Follow this and additional works at: https://researchrepository.wvu.edu/wvlr

\section{Recommended Citation}

Virginia Colonial Decisions, 28 W. Va. L. Rev. (1921).

Available at: https://researchrepository.wvu.edu/wvlr/vol28/iss1/22

This Notice is brought to you for free and open access by the WVU College of Law at The Research Repository @ WVU. It has been accepted for inclusion in West Virginia Law Review by an authorized editor of The Research Repository @ WVU. For more information, please contact ian.harmon@mail.wvu.edu. 
The man into whose house a wayfarer has come for shelter from a storm will have difficulty in sympathizing with his uninvited guest if he begins complaining that the house is insufficiently heated and the furniture uncomfortable. And the owner of the house will perhaps be pardoned for suggesting a departure if the stranger intimates the intention of pulling down the house and making it over to suit himself.

Heeding the principles of the book, we have ventured to indulge in a reviewer's freedom of speech, realizing that Professor Chafee is estopped by his own principles from calling us to account for our conclusions. But, in addition, the fine good humor with which he has expounded his very definite views secures us, we know, his full dispensation.

-Henry Wolf Biklé.

Law School,

University of Pennsylvania.

Carlin's Edition of Hogg's Equity Procedure.-The QuarTERLY is pleased to call the attention of the members of the Bar to the revision of Fogg's Equity Procedure. This work has been done by Professor Leo Carlin of the College of Law, West Virginia University.

New Edition of Coat, OH, Gas, Limestone and Iron Ore MaP.-The West Virginia Geological Survey has recently published this new map of valuable information and interest. The QUARTERLY acknowledges receipt of a copy.

Virginia Coloniat Decisions.-A collection of these important decisions is for sale by one of our advertisers. The QuARTERLY makes this mention because of the peculiar and historical interest of this publication to members of the West Virginia Bar. 